\title{
Endonasal endoscopic approach in pituitary adenomas: surgical results
}

\author{
Omar López Arbolay*, Jorge L. Rojas Manresa and Yusleni Hernández Gálvez \\ *Correspondence: arbolay@infomed.sld.cu \\ Neurosurgery Department of “Hermanos Ameijeiras” Hospital, 701 San Lazaro, St. Centro Habana. La Habana. Cuba.
}

\begin{abstract}
Objectives: Pituitary adenomas are the most common disorders of the sellar region seen in neurosurgical practice. Surgical excision through the transsphenoidal route is recognized as the best option to treat these lesions and the endonasal endoscopic approach (EEA) has been introduced in many centers. This article analyzes results using this technique.

Material and methods: EEA was used to operate on 278 patients at the Neurosurgery Department of "Hermanos Ameijeiras" Hospital in Havana from January 2005 to December of 2011.

Results: Two hundred thirty eight patients had pituitary macroadenomas and forty had microadenomas. Ninety two were functioning adenomas (52 GH, $34 \mathrm{ACTH}$ and $6 \mathrm{PRL})$ and one hundred eighty six were non-functioning. Gross total resection was achieved in $92.4 \%$ and subtotal resections in $7.5 \%$. Complications occurred in 25 patients; diabetes insipidus was permanent in 11 cases.

Conclusion: Because of the remarkable results for treating pituitary lesions, EEA has become a valuable technique in neurosurgical practice and in many centres has become the first option to consider in pituitary surgery.
\end{abstract}

Keywords: Endoscopic, approaches, pituitary, adenomas

\section{Introduction}

Disorders of the sellar region are frequently encountered in neurosurgical practice. Pituitary adenomas accounts for $10 \%$ $15 \%$ of all intracranial tumors $[1,2]$ and represent up to a third of all primary tumors affecting the central nervous system [3-5]. In autopsy series, the incidental finding of pituitary adenomas is relatively common in adults (24\% of cases) [4,5]. Medical treatment is indicated in some secreting adenomas such as prolactin secreting adenomas and for others such as growth hormone and ACTH secreting adenomas. With non-secreting adenomas surgery usually constitutes the first line of treatment and medical treatment is supplementary.

Endoscopic approaches used for paranasal sinus surgery were reported in the early 70 s and their use expanded during the next 2 decades [5-11]. Some recent reports have suggested that the endoscope is replacing the microscope in pituitary surgery $[\mathbf{8}, 10,12-14]$.

The senior author has used the endoscope with the transsphenoidal approach since 2000 [15]. Gradually, we expanded the use of endoscopic maneuvers and by 2004 the endoscopic approach had replaced the microscopic approach for pituitary lesions. This article analyzes results using this technique over the past five years.

\section{Patients and method}

In this study, we retrospectively analyzed the surgical outcomes of 278 patients with pituitary adenomas using the endoscopic approach in the neurosurgical department of the hermanos ameijeiras hospital, havana between january 2005 and december 2011.

Patients harboring non-secreting macroadenomas and GH or ACTH (micro or macro) secreting adenomas were included as well as PRL secreting macroadenomas with severe visual deficits that didn't respond to medical treatment. Excluded from this series are patients with microprolactinomas (less than 10mm) and non-functioning microadenomas that received medical treatment as well as adenomas with large extensions to the parasellar area (eg., lateral compartment of cavernous sinus), that required extended endoscopic approaches. Patient that required re-intervention were excluded too.

The preoperative protocol included endocrine, neuroradiological, and neuro-ophthalmological evaluation. Hormone tests such as cortisol, free thyroxin, thyrotropin (TSH), corticotropin (ACTH), prolactin (PRL), growth hormone $(\mathrm{GH})$, luteinizing hormone $(\mathrm{LH})$, follicle-stimulating hormone and testosterone were performed. When Cushing's disease was suspected, a dexamethasone suppression test was done and in cases of acromegaly, $\mathrm{GH}$ enhanced glucose tolerance was performed. CT scans and MRI imaging of sellar and parasellar regions were performed in every case. Neuro-ophthalomological evaluation included formal visual-field and visual acuity testing. The following variables were assessed: Type of lesion, imaging and endocrinological features, postoperative outcomes, and complications.

Prior to the surgery, informed consent was obtained from 
López Arbolay et al. Neuroscience Discovery 2013,

Table 1. Lesions.

\begin{tabular}{l|cccc}
\hline \multirow{2}{*}{ Adenomas } & Macroadenomas & Microadenomas & \multicolumn{2}{c}{ Total } \\
\cline { 2 - 6 } & $\#$ & $\#$ & $\#$ & $\mathbf{\%}^{*}$ \\
\hline $\begin{array}{l}\text { GH secreting } \\
\text { adenomas }\end{array}$ & 40 & 12 & $\mathbf{5 2}$ & 18.7 \\
$\begin{array}{l}\text { ACTH secreting } \\
\text { adenomas }\end{array}$ & 6 & 28 & $\mathbf{3 4}$ & 12.2 \\
$\begin{array}{l}\text { PRL secreting } \\
\text { adenomas }\end{array}$ & 6 & -- & $\mathbf{6}$ & 2.1 \\
$\begin{array}{l}\text { Non secreting } \\
\text { adenomas }\end{array}$ & 186 & -- & $\mathbf{1 8 6}$ & 66.9 \\
Total & $\mathbf{2 3 8}$ & $\mathbf{4 0}$ & $\mathbf{2 7 8}$ & $\mathbf{1 0 0}$ \\
\hline
\end{tabular}

*Based on the total number of adenomas (n- 278 cases)

Table 2. Postoperative Radiological Evaluation (n-278).

\begin{tabular}{c|cc}
\hline \multirow{2}{*}{ Lesions } & \multicolumn{2}{|c}{ Imagenological Evaluation } \\
\cline { 2 - 3 } & Total Removal & Remain \\
\hline Macroadenomas (n-238) & $217(91.1 \%)$ & $21(8.8 \%)$ \\
Microadenomas (n-40) & $40(100 \%)$ & 0 \\
Total & $\mathbf{2 5 7 ( 9 2 . 4 \% )}$ & $\mathbf{2 1}(\mathbf{7 . 5 \% )}$ \\
\hline
\end{tabular}

each patient involved in the study.

With each patient postoperative neurological status, a full endocrinological assessment, and postoperative MRI scans were repeated. A CT scan was usually done the day after the surgery in order to diagnose possible complications. MRI scanning was routinely performed on all patients at 3, 6 and 12 months after the surgery and annually thereafter. Gross total removal (GTR) was considered when surgical observation along with the postoperative imaging confirmed the absence of any visible tumor. In all cases the surgical specimens were studied and classified by immunohistochemistry techniques.

In patients with functioning adenomas, surgical cure was based on clinical remission and postoperative hormonal results c (in Acromegaly $\mathrm{GH} \leq 1 \mathrm{ng} / \mathrm{mL}$ and GH nadir of $0.2 \mathrm{ng} /$ $\mathrm{ml}$ or less after an oral glucose tolerance test performed at 3 and 6 mouths; in Cushing's disease morning cortisol level measurement $\leq 100 \mathrm{nmol} / \mathrm{L}$ requiring substitutive therapy obtained in the first 48 hours after surgery along with the suppression to low-dose dexamethasone and normalization of the 24-hour urinary free cortisol at 3 and 6 mouths and in prolactinomas, PRL level $\leq 20 \mathrm{ng} / \mathrm{mL}$ ). Patients who did not satisfy these criteria were not considered to be cured.

\section{Surgical technique}

Using two rigid 18 centimeter length, 4 milimeters diameter, 0 and 30 degrees endoscopes (Karl Storz), our surgical technique is basically the same as described by Jho and Carrau [10]. The initial step is resection of the middle turbinate. Next the sphenoid ostium is localized; however this may not be visible in more than $30 \%$ of patients [16] and in these cases the sphenoid sinus is entered by drilling the sphenoid rostrum.
A large sphenoidotomy is performed exposing the sellar floor from one carotid prominence to the other and from the planum sphenoidale to the clival recess. Both optic-carotid recesses (medial and lateral) are routinely visualized. We usually resect a small part of the posterior nasal septum, allowing greater maneuverability of instruments thus increasing the efficacy and safety of the surgery by improving access to the tumour, as well as allowing better hemostasis.

We perform the procedure using a bimanual technique via a binasal approach, with the assistant surgeon holding the endoscope.

When adenomas have large but midline suprasellar extensions, more anterior bony resection of the sellae tuberculum or sphenoidale planum is performed, making it possible to gain more superior access, and apply gentle downwards traction to deliver the dome of the tumour.

The closure is done by multilayer method, using a free inlaid fat pad graft (intradural) and a bone fragment (epidural) as an onlay graft. In cases of macroadenomas with suprasellar extensions with heightened risk of perioperative cerebrospinal fluid (CSF) leak, this multilayer closure is supplemented with a mucosal nasoseptal flap. [17]. This is supported by a 12 French Foley balloon catheter in order to compress the multilayer reconstruction against the defect. No nasal packing is used.

\section{Results}

Two hundred thirty eight patients with macroadenomas and forty with microadenomas were operated on using the EEA technique. Ninety two were functioning tumors $(52 \mathrm{GH}, 40$ $\mathrm{ACTH}$ and $6 \mathrm{PRL}$ ) and one hundred eighty six non-functioning (Table 1).

Headache and visual field impairment were the most common complaints in patients with non-functioning adenomas. In patients with secreting tumors the clinical presentation depended on the increased hormone. (i.e., PRL, $\mathrm{GH}$ or $\mathrm{ACTH}$ ).

Postoperative imaging showed total removal in $92.4 \%$ of the patients and residual tumor in $7.5 \%$ ( Table 2).

Postoperative hormone evaluation in patients with secreting adenomas (92 cases) showed remission in $89.1 \%$ and improvement in $9.7 \%$. Patients having ACTH, GH and PRL secreting adenomas in this order, achieved better results (Table 3).

Postoperative neuro-ophthalmological evaluation revealed that $65.9 \%$ of 138 patients with previous visual deficits have returned to baseline, $28.2 \%$ have improved and $5.7 \%$ were unchanged (Table 4).

Postoperative morbidity occurred in 25 patients (8.9\%) (Table 5).

Thirty-three patients developed CSF leak during surgery, but this was repaired immediately using the multilayer closure described above including in the last two years, the mucosal nasoseptal flap. Four patients developed CSF leaks in the postoperative period two of whom required surgical 
López Arbolay et al. Neuroscience Discovery 2013,

Table 3. Postoperative Hormonal Evaluation in secreting adenomas. n-92.

\begin{tabular}{l|cccccc}
\hline \multirow{2}{*}{$\begin{array}{c}\text { Type of hormonal } \\
\text { secreting }\end{array}$} & \multicolumn{5}{|c}{ Postoperative Hormonal Evaluation } \\
\cline { 2 - 7 } & Remission & \multicolumn{1}{c}{ Improvement } & \multicolumn{2}{c}{ Similar } \\
\cline { 2 - 7 } & $\#$ & \%* $^{*}$ & $\#$ & \%* $^{*}$ & $\#$ & \%* $^{*}$ \\
\hline GH & 44 & $84.6 \%$ & 7 & $13.4 \%$ & 1 & $1.9 \%$ \\
ACTH & 32 & $92.6 \%$ & 2 & $7.4 \%$ & -- & -- \\
PRL & 6 & $100 \%$ & -- & -- & -- & -- \\
Total & $\mathbf{8 2}$ & $\mathbf{8 9 . 1 \%}$ & $\mathbf{9}$ & $\mathbf{9 . 7 \%}$ & $\mathbf{1}$ & $\mathbf{1 . 1} \%$ \\
\hline
\end{tabular}

*The percentages were determined for each category

Table 4. Postoperative Neuro-ophthalmological Evaluation. $(\mathrm{n}=138)$.

\begin{tabular}{l|lll}
\hline \multirow{2}{*}{\begin{tabular}{c}
\multirow{2}{*}{$\begin{array}{c}\text { Previous Visual } \\
\text { Defect }\end{array}$} \\
\cline { 2 - 4 }
\end{tabular}} & \multicolumn{3}{|c}{$\begin{array}{c}\text { Postoperative Neuro-ophthalmological } \\
\text { Evaluation }\end{array}$} \\
\cline { 2 - 4 } & Disappearence & Improvement & Unchanged \\
\hline Hemianopsia & 62 & 13 & -- \\
$\begin{array}{l}\text { Quadrantanopsia } \\
\text { Tubular vision }\end{array}$ & 29 & 1 & -- \\
$\begin{array}{l}\text { Unilateral Amaurosis } \\
\text { and contralateral }\end{array}$ & -- & 1 & -- \\
hemianopsia & & 24 & 8 \\
Total & $\mathbf{9 1 ( 6 5 . 9 \% )}$ & $\mathbf{3 9 ( 2 8 . 2 \% )}$ & $\mathbf{8 ( 5 . 7 \% )}$ \\
\hline
\end{tabular}

Table 5. Postoperative morbidity (n-278).

\begin{tabular}{lcc}
\hline Complication & $\#$ & \% \\
\hline CSF leak & 4 & 1.4 \\
Meningitis & 3 & 1.1 \\
Diabetes Insipidus & 11 & 3.9 \\
Pan-hypopituitarism & 4 & 1.4 \\
Partial Hypopituitarism & 10 & 3.6 \\
Hydrocephalus & 1 & 0.3 \\
Selar tension hematoma & 2 & 0.7 \\
Total & $\mathbf{2 5}$ & $\mathbf{8 . 9}$ \\
\hline
\end{tabular}

intervention where nasoseptal flap displacement was found and repaired. Hydrocephalus was diagnosed in one case and a ventriculo-peritoneal shunt was inserted. Two patients suffered visual field deterioration in the immediate postoperative period due to sellar and suprasellar hematomas which were successfully evacuated with uneventful recovery. Three patients suffered bacterial meningitis, with complete resolution after antibiotic treatment. From the endocrine point of view, four cases suffered pan-hypopituitarism requiring substitute treatment; permanent diabetes insipidus occurred in $11(3.9 \%)$ and ten patients (3.6\%) had some degree of partial hypopituitarism.There were no deaths in this series.

\section{Discussion}

The endoscopic approach to the sellar region was developed from a combination of pre-existing techniques (transnasaltransseptal-transsphenoidal and endonasal-transsphenoidal approaches) [7]. Rodziewics [18] performs the operation through both nostrils. He introduces the endoscope through the left nostril into an $8 \mathrm{~mm}$ incision in the posterior nasal mucosa and operative instruments are introduced through the sub-mucosal tunnel in the right nostril in order to avoid interference between them. The only difference between this and the standard microscopic technique is that the cartilaginous septum is not dislocated from the nasal spine. The risks of mucosal adhesions, esthetic changes and postoperative discomfort are increased by the mucoseptal dissection. Recent cases series have been reported using the unilateral and endonasal approach with very good results $[11,19]$. This technique avoids the trauma, as well as the additional surgical time necessary to dissect the mucoseptum. The fact that use of the endoscope leads to superior visualization in pituitary surgery is generally acknowledged [16]. Resection of the middle turbinate has been recommended in order to enlarge the approach, improve the view and facilitate passage of the surgical instruments and endoscope [8]. In our experience, it was only necessary if lateralization of the middle turbinate was insufficient. It is useful to select the larger nostril and gradually advance the endoscope along the floor of the nasal cavity between the inferior turbinate and the nasal septum up to the choana and then angle it along the roof of the choana to identify the spheno-ethmoid recess and sphenoid rostrum $[10,19]$.

In the future, development of stereoscopic endoscopes will add a three-dimensional perspective to the surgical field, closer to the current microscopic view [20]. Nevertheless the bi-dimensional view offered by the endoscope allows better definition of the anatomical target and interface between the tumor and the adjacent glandular tissue and arachnoid. As well as, it provides a panoramic vision of the surgical field and offers the possibility to identify clearly structures in sphenoid sinus such as the sellar floor, optic and carotid protuberances, opto-carotid recess and suprasellar cistern. In addition, different lenses ( 30 and 45 degrees) allow visualizing some suprasellar structures, when tuberculum and planum sphenoidale are removed; this provides access to tumor fragments in these areas.

Regardless of these benefits, endoscopic surgery is not a panacea. Blood on the tip of the lens affects the view and its removal adds time to the operation. Although the irrigationsuction system offers the possibility of continuing cleansing of the tip, this is one of the most annoying problems to overcome [21]. Jho and Carrau [10] in 1997 reported their first experience, having achieved relief of the symptoms in 13 of 14 patients with pituitary adenomas operated by an endoscopic approach. Heilman [22] totally removed the lesions in 2 of 5 patients with pituitary adenomas, with symptomatic and hormonal improvement in other 2; while in one patient with Cushing disease, the cortisol levels stayed elevated. D'Haens [23] achieved better results using a fully endoscopic endonasal technique compare with results obtained previously using the traditional microsurgical transsphenoidal procedure. 
López Arbolay et al. Neuroscience Discovery 2013,

With regard to functioning adenomas, in the last two years, the rate of remission has been influenced and improved by the use of synthetic octreotide (Sandostatin Lar) three months before the surgery in $\mathrm{GH}$-secreting macroadenomas, and $\mathrm{ACTH}$-secreting adenomas and the preoperative use of Cabergoline in cases with prolactin-secreting adenomas. Most of these were microadenomas and the other were intrasellar macroadenomas.

Visual recovery in our experience was influenced by the severity of visual loss at the time the patient had surgery. Patients without optic atrophy who had surgery shortly after the diagnosis had better recovery in their vision whereas. those in whom surgery was delayed or who had optic atrophy achieved little improvement.

We achieved total removal in $89.6 \%$ of macroadenomas. Factors we consider to be responsible for these results include wide opening at the sphenoid rostrum and sellar floor and extension of the bony resection to the tuberculum sella or part of the planum sphenoidale when necessary to gain access to the suprasellar part of the tumor. These results are similar to the reported by Dehdashti et al., [16] and they are also similar to the microscopic standard technique [15] and even better than other series of adenomas operated by standard microsurgical techniques [16,21].

With regard to complications, cerebral spinal fluid leak was one of our most common complications as reported by others [19]. This is encountered more frequently in cases of macroadenomas with extensive suprasellar extension requiring opening of the subarachnoid space during the dissection. In these cases watertight repair of the cranial base defect is mandatory. Different techniques in reconstructing the sellar floor have been used combining abdominal fat, fascia lata, mucoperiosteum and bone; more recently the nasoseptal flap has also been used [17].

In one of our cases who developed hydrocephalus there was not a clearcut etiology; contamination of CSF with blood products may have predisposed to CSF malabsorption.

Two of our patients required immediate reoperation for hematomas in the sellar and suprasellar areas. Meningitis occurred in 3 patients who were treated successfully with antibiotics. Diabetes insipidus occurred in 11 of our patients and panhypopituitarism in 4; both complications were controlled with replacement therapy. Other complications observed with some frequency in microscopic transphenoidal surgery such as postoperative facial swelling due to dissection and placement of the speculum and naso-septal synechiae were absent in our series. This together with the lack of requiring nasal packs make the postoperative period more comfortable following endoscopic surgery. Papay reports that the endoscopic transnasal transeptal approach has a lower incidence of bleeding and minor morbidity than the microscopic approach in his hands [24].

Although not considered in this series, re-intervention after previous transsphenoidal surgery is commonly acknowledged to be difficult. Factors such as distorted anatomy, fibrous scars, discontinuous septum and conditions like mucoceles can make the surgery very tedious and keeping the integrity of the mucosa is very challenging $[16,25]$. The rates of these complications seem to be similar in previous endoscopic and microscopic reports [26-29]. However, some authors have reported less pain and postoperative discomfort in comparison with the first operation in patients who required repeat surgery after a first endoscopic procedure [22].

The learning curve for endoscopic pituitary surgery can be prolonged for surgeons who do not use the endoscope since different skills have to be mastered [9]. In order to shorten this process, it has been suggested that endoscopic instruments be first used during standard approaches. Others have tried to improve the quality of the instruments to increase the safety of this operation in un-experienced hands [25].

\section{Conclusion}

The advantages of the full endoscopic approach for the treatment of pituitary adenomas, despite some limitations, are illustrated by our experience and that of others $[16,19,25,30-33]$ it is an effective and reliable method and is now considered the preferred procedure for most pituitary tumours in many centres.

\section{Competing interests}

The authors declare that they have no competing interests.

\section{Authors' contributions}

LA was the principal neurosurgeon, conceived research and performed the article. RM was the second neurosurgeon and HG made critical revision of the manuscript.

\section{Acknowledgement}

We thank to Renn Holnes for the revision of this article. The studies and surgery reported in this paper have been performed under the auspices of the ethics and scientific committee of "Hermanos Ameijeiras" Hospital and were supported completely by Public Health Ministry. This article and authors don't have conflicts of interest neither ethical problem.

\section{Publication history}

EIC: Tadanori Tomita, Northwestern University Feinberg School of Medicine, USA.

Received: 01-Apr-2013 Revised: 14-Jul-2013

Accepted: 14-Aug-2013 Published: 20-Aug-2013

\section{References}

1. Greenberg MS. Tumor-Pituitary Adenomas. In: Greenberg MS, fifth eds. Handbook of Neurosurgery. Lakeland FI: Greenberg Graphics 2001; 419436. I Book

2. Cappabianca $P$ and de Divitiis E. Endoscopy and transsphenoidal surgery. Neurosurgery. 2004; 54:1043-48. | Article I PubMed

3. Jane JA, Jr. and Laws ER, Jr. The surgical management of pituitary adenomas in a series of 3,093 patients. J Am Coll Surg. 2001; 193:651-9. | Article | PubMed

4. Tomita $T$ and Gates E. Pituitary adenomas and granular cell tumors. Incidence, cell type, and location of tumor in 100 pituitary glands at autopsy. Am J Clin Pathol. 1999; 111:817-25. | PubMed 
López Arbolay et al. Neuroscience Discovery 2013,

5. Cavallo LM, Messina A, Cappabianca P, Esposito F, de Divitiis E, Gardner P and Tschabitscher M. Endoscopic endonasal surgery of the midline skull base: anatomical study and clinical considerations. Neurosurg Focus. 2005; 19:E2. | Article | PubMed

6. Jane JA, Jr., Han J, Prevedello DM, Jagannathan J, Dumont AS and Laws ER, Jr. Perspectives on endoscopic transsphenoidal surgery. Neurosurg Focus. 2005; 19:E2. | Article | PubMed

7. Papay FA, Benninger MS, Levine HL and Lavertu P. Transnasal transseptal endoscopic repair of sphenoidal cerebral spinal fluid fistula. Otolaryngol Head Neck Surg. 1989; 101:595-7. I PubMed

8. Jankowski R, Auque J, Simon C, Marchal JC, Hepner H and Wayoff M. Endoscopic pituitary tumor surgery. Laryngoscope. 1992; 102:198-202. | Article | PubMed

9. Carrau RL, Jho HD and Ko Y. Transnasal-transsphenoidal endoscopic surgery of the pituitary gland. Laryngoscope. 1996; 106:914-8. | Article I PubMed

10. Jho HD, Carrau RL, Ko Y and Daly MA. Endoscopic pituitary surgery: an early experience. Surg Neurol. 1997; 47:213-22; discussion 222-3. | Article | PubMed

11. Jho HD and Carrau RL. Endoscopic endonasal transsphenoidal surgery: experience with 50 patients. J Neurosurg. 1997; 87:44-51. | Article | PubMed

12. Sethi DS and Pillay PK. Endoscopic pituitary surgery: a minimally invasive technique. Am J Rhinol. 1996; 10:141-147. | Article

13. Cavallo LM, Dal Fabbro M, Jalalod'din H, Messina A, Esposito I, Esposito F, de Divitiis E and Cappabianca P. Endoscopic endonasal transsphenoidal surgery. Before scrubbing in: tips and tricks. Surg Neurol. 2007; 67:3427. | Article | PubMed

14. Sheehan MT, Atkinson JL, Kasperbauer JL, Erickson BJ and Nippoldt TB. Preliminary comparison of the endoscopic transnasal vs the sublabial transseptal approach for clinically nonfunctioning pituitary macroadenomas. Mayo Clin Proc. 1999; 74:661-70. | Article | PubMed

15. González J, López-Arbolay O, Morales O, et al. Cirugía transnasal transesfenoidal endoscópica en afecciones de la región selar. Revista Española de Neurocirugía. 2005; 16:27-33. | Article

16. Dehdashti AR, Ganna A, Karabatsou K and Gentili F. Pure endoscopic endonasal approach for pituitary adenomas: early surgical results in $\mathbf{2 0 0}$ patients and comparison with previous microsurgical series. Neurosurgery. 2008; 62:1006-15. | Article | PubMed

17. Hadad G, Bassagasteguy L, Carrau RL, Mataza JC, Kassam A, Snyderman $\mathrm{CH}$ and Mintz A. A novel reconstructive technique after endoscopic expanded endonasal approaches: vascular pedicle nasoseptal flap. Laryngoscope. 2006; 116:1882-6. | Article | PubMed

18. Rodziewicz GS, Kelley RT, Kellman RM and Smith MV. Transnasal endoscopic surgery of the pituitary gland: technical note. Neurosurgery. 1996; 39:189-92. | Article | PubMed

19. Cappabianca P, Alfieri A and de Divitiis E. Endoscopic endonasal transsphenoidal approach to the sella: towards functional endoscopic pituitary surgery (FEPS). Minim Invasive Neurosurg. 1998; 41:66-73. | Article | PubMed

20. Tabaee A, Anand VK, Fraser JF, Brown SM, Singh A and Schwartz TH. Three-dimensional endoscopic pituitary surgery. Neurosurgery. 2009; 64:288-93. | Article | PubMed

21. Ciric I, Mikhael M, Stafford T, Lawson L and Garces R. Transsphenoidal microsurgery of pituitary macroadenomas with long-term follow-up results. J Neurosurg. 1983; 59:395-401. | Article | PubMed

22. Heilman CB, Shucart WA and Rebeiz EE. Endoscopic sphenoidotomy approach to the sella. Neurosurgery. 1997; 41:602-7. | Article | PubMed

23. D'Haens J, Van Rompaey K, Stadnik T, Haentjens P, Poppe K and Velkeniers $B$. Fully endoscopic transsphenoidal surgery for functioning pituitary adenomas: a retrospective comparison with traditional transsphenoidal microsurgery in the same institution. Surg Neurol. 2009; 72:336-40. | Article | PubMed

24. Papay FA, Stein JM, Rhoten RL, Luciano M, Zins J and Hahn J. Transnasal transseptal endoscopic approach to the sphenoid sinus. J Craniofac
Surg. 1997; 8:159-63. | Article | PubMed

25. Cappabianca P, Alfieri A, Thermes S, Buonamassa $S$ and de Divitiis $E$. Instruments for endoscopic endonasal transsphenoidal surgery. Neurosurgery. 1999; 45:392-5. | Article | PubMed

26. de Divitis E, Cavallo M. Endoscopic Endonasal Transsphenoidal Approach to the Sellar Region. Wien Springer 2003. | Book

27. Jho HD. Endoscopic transsphenoidal surgery. J Neurooncol. 2001; 54:187-95. | Article | PubMed

28. Semple PL and Laws ER, Jr. Complications in a contemporary series of patients who underwent transsphenoidal surgery for Cushing's disease. J Neurosurg. 1999; 91:175-9. | Article | PubMed

29. Zada G, Kelly DF, Cohan P, Wang C and Swerdloff R. Endonasal transsphenoidal approach for pituitary adenomas and other sellar lesions: an assessment of efficacy, safety, and patient impressions. $J$ Neurosurg. 2003; 98:350-8. | Article | PubMed

30. Senior BA, Ebert CS, Bednarski KK, Bassim MK, Younes M, Sigounas D and Ewend MG. Minimally invasive pituitary surgery. Laryngoscope. 2008; 118:1842-55. | Article | PubMed

31. Zhang $Y$, Wang Z, Liu $Y$, Zong $X$, Song $M$, Pei A, Zhao $P$, Zhang $P$ and Piao $M$. Endoscopic transsphenoidal treatment of pituitary adenomas. Neurol Res. 2008; 30:581-6. | Article | PubMed

32. Charalampaki P, Ayyad A, Kockro RA and Perneczky A. Surgical complications after endoscopic transsphenoidal pituitary surgery. J Clin Neurosci. 2009; 16:786-9. | Article | PubMed

33. Arbolay OL, Gonzalez JG, Gonzalez RH and Galvez YH. Extended endoscopic endonasal approach to the skull base. Minim Invasive Neurosurg. 2009; 52:114-8. | Article | PubMed

\section{Citation:}

O. López Arbolay, J. L. Rojas Manresa and Y. Hernandez Galvez. Endonasal endoscopic approach in pituitary adenomas: surgical results. Neurosci Discov. 2013; 1:5. http://dx.doi.org/10.7243/2052-6946-1-5 